\title{
Community-level interactions between ungulate browsers and woody plants in an African savanna dominated by palatable-spinescent Acacia trees
}

\section{D.A. Fornara ${ }^{a, c}$ and J.T. du Toit ${ }^{\text {b, c }}$}

a Department of Ecology, Evolution and Behavior, University of Minnesota, St. Paul, MN 55108, USA

b Department of Wildland Resources, Utah State University, Logan, UT 84322-5230, USA

c Department of Zoology \& Entomology, Mammal Research Institute, University of Pretoria, South Africa

\section{Abstract}

We studied the composition of a savanna woody plant community across a natural herbivory gradient maintained by both browsing and grazing ungulates in an arid part of the Kruger National Park, South Africa. We focused on (1) short-term browsing effects on reproductive and morphological traits of a dominant-palatable woody species, Acacia nigrescens, Miller, (2) the relationship between browsing-grazing intensity and soil parameters, (3) the effects of herbivore-soil interactions on woody species richness and composition, and (4) browser-induced effects on the representation of woody plant functional traits.

We show that the number of pods carried by A. nigrescens trees as well as the internode length of external tree branches both decreased significantly at high browsing intensity. Moreover, we found that total soil nitrogen $(\mathrm{N})$ and soil cation $(\mathrm{Ca}, \mathrm{Na}, \mathrm{Mg}$, and $\mathrm{K}$ ) concentrations varied significantly according to grazing rather than browsing intensity with soil nutrients decreasing at heavily grazed sites. Although herbivory and soil 
properties together explained $\sim 79 \%$ of the total variability in woody species composition, neither herbivory intensity nor soil properties taken separately could explain variation in woody species richness across sites. Browsing intensity could also not account for variation in the mix of evergreen, spinescent and preferred browse plants across sites. Ordination analysis showed that the palatable but spinescent $A$. nigrescens had the lowest fit on the first two ordination axes and was distributed across study sites irrespective of herbivory intensity and soil properties. We suggest that community-level interactions between browsers and woody plants are different in arid eutrophic African savannas where the dominance by spinescent trees might prevent shifts in species composition under high browsing intensity, which is contrary to what has been observed in woodlands at higher latitudes.

\section{Article Outline}

1. Introduction

2. Material and methods

2.1. Study area

2.2. Sampling design

3. Data analysis

4. Results

4.1. Effects of distance from permanent surface water on browsing and grazing intensity 4.2. Effects of ungulate browsing on pod production and internode length

4.3. Effects of browsing and grazing intensity on soil parameters

4.4. Plant community composition and species distribution

5. Discussion

Acknowledgements

Appendix 1. Appendix

References 


\section{Introduction}

Large mammalian herbivores indirectly determine changes in the structure and dynamics of vegetation communities across terrestrial ecosystems (Augustine and McNaughton, 1998; Belsky, 1984; Harmer, 2001; Jachmann and Croes, 1991; McInnes et al., 1992). At high latitudes, selective browsing on palatable trees and shrubs (Brookshire et al., 2002; Heikkilä and Härkönen, 1996; Motta, 2003; Rao et al., 2003) negatively affects species with nutrient-rich tissues (Peinetti et al., 2001; Ritchie et al., 1998) and contributes to an early dominance of unpalatable species within the plant community (Horsley et al., 2003; Wardle et al., 2001). Therefore, long-term browsing in N-limited systems, such as boreal forests might negatively affect nutrient cycling and speed up the vegetation succession to later stages dominated by evergreens (Kielland and Bryant, 1998; Pastor and Naiman, 1992; Pastor et al., 1988).

The extent to which large herbivores might affect plant physiognomy and community structure is expected to be most obvious in eastern and southern African savannas, where biomass densities of mammalian herbivores are at the highest levels yet quantified in terrestrial ecosystems (McNaughton and Georgiadis, 1986), as is predicted by the favorable combination of precipitation and soil fertility (Olff et al., 2002). Moreover, variation in diet and habitat selectivity across ungulate species, which results from variation in body size and dietary tolerance (du Toit and Owen-Smith, 1989) overlaid upon gross functional differences between grazing and browsing guilds (Fritz et al., 2002; Prins and Douglas-Hamilton, 1990), contributes to the high heterogeneity of savanna landscapes (du Toit, 2003). Finally, soil nutrient heterogeneity and herbivore-soil feedbacks have been recognized as a key determinant of the abundance and distribution of large mammalian herbivores in many natural and managed savanna ecosystems (Augustine et al., 2003; McNaughton et al., 1988). Yet despite the strong research interest in the stability and dynamics of African rangelands, there has been a surprising lack of research on the interactions between savanna herbivores, woody plants, and soil properties, which could inform the managers of large protected areas. In the Kruger National Park, one of the largest conservation areas in Africa, trends in woody vegetation structure and composition have been historically explained by the effects of fire and 
elephants, Loxodonta africana (see Eckhardt et al., 2000; Whyte et al., 2003). Published studies on the effects of browsing on woody plant ecology have been confined to the central region of the Park (du Toit, 2003; du Toit et al., 1990; see also Naiman et al., 2003) and none have sought to separate the effects of large herbivores and soil properties on the composition and structure of savanna woodlands. In African savannas browsinginduced effects have been described as (1) limiting woodland regeneration (Belsky, 1984; [Augustine and McNaughton, 1998] and [Augustine and McNaughton, 2004]), (2) affecting vegetation structure (Augustine and McNaughton, 2004; Pellew, 1983), and (3) influencing species composition and distribution (Bond and Loffell, 2003). However, vegetation responses under chronic browsing pressure are sometimes contradictory and do not always lead to a clear dominance of less-preferred species (Jachmann and Bell, 1985; Tilghman, 1989) due probably to the compensatory growth abilities of preferred species (Augustine and McNaughton, 1998; du Toit et al., 1990; Oba and Post, 1999). A recent research study in the arid eutrophic basaltic plains of Kruger (Fornara and du Toit, 2007) showed that the combination of physical defences (i.e. thorns and prickles) and high plant compensatory growth abilities was crucial to promote the persistence of heavily browsed $A$. nigrescens stands in a hedged state suggesting the idea of 'browsing lawns'. However, Acacia trees can still be eaten by browsers and this might have negative effects on tree reproduction in severely pruned trees (Goheen et al., 2007). Our study was set up at the landscape scale on the arid eutrophic plains of central Kruger where we identified a strong natural herbivory gradient, which has existed for decades and presumably centuries. The distribution of permanent and seasonal watering points drives savanna heterogeneity at the landscape scale by controlling the distribution of biomass within the large herbivore community (Naiman et al., 2003; Redfern et al., 2003). Therefore, by selecting sites near to and far from water, we were able to investigate the effects of ungulate herbivory on woody plant community structure in a 'natural experiment' sensu (Diamond, 1986). We specifically tested the following predictions:

(1) Pod production and internode length of external branches of the palatable-dominant A. nigrescens are negatively affected by browsing intensity. 
(2) Variation in soil parameters along the herbivory gradient is driven more by the effects of grazers than browsers.

(3) Browsing ungulates are responsible for changes in the functional properties and composition of woody plant communities, with an increased representation of lesspreferred woody species (especially evergreens) in areas of higher browsing intensity.

\section{Material and methods}

\subsection{Study area}

The study was conducted in a central region of the Kruger National Park, based at the Tshokwane ranger station $\left(24^{\circ} 47^{\prime} \mathrm{S}, 31^{\circ} 52^{\prime} \mathrm{E}\right)$. The experiments were carried out in the "Satara land system", which consists mainly of fine-leaved tree savanna or bushveld, dominated by A. nigrescens, Sclerocarya birrea and Dichrostachys cinerea (Venter et al., 2003). Rainfall regime averages $556 \mathrm{~mm}$ per annum, with $80 \%$ of the precipitation concentrated in the wet season from October to March. However, the climatic conditions during our period of study were particularly dry given that from September 2002 to November 2003 rainfall in the Tshokwane section of Kruger was less than $200 \mathrm{~mm}$ in total. The study was set up in an area of $\approx 6500$ ha where the last fire event occurred in 1990; prior to that, in 1979 and 1984, respectively, 80\% and 70\% of the study area was burnt. Between 1968 and 1979 there were 11 minor fires among which the largest burnt $\sim 30 \%$ of the study area. The ungulate browsing guild is mainly composed of giraffe (Giraffa camelopardis), kudu (Tragelaphus strepsiceros), steenbok (Raphicerus campestris), and the mixed feeders impala (Aepyceros melampus) and elephant. Previous studies on the Kruger browsing guild (du Toit and Owen-Smith, 1989; du Toit et al., 1990; Owen-Smith, 1990; Owen-Smith, 1979), and historical data from Kruger (Mabunda et al., 2003) indicate that the vegetation has experienced current levels of mammalian herbivory for many decades and presumably for centuries, apart from a few decades following the effectively synchronous rinderpest panzootic and elephant overhunting episode near the end of the 19th century. 


\subsection{Sampling design}

We selected nine sites according to their distance from surface water: three heavily trampled sites were identified as highly browsed and highly grazed (HH), situated $<1.5 \mathrm{~km}$ from water sources and vegetated by severely pruned A. nigrescens trees; three sites were highly browsed but lightly grazed (HL) $<4 \mathrm{~km}$ from permanent water; finally, three sites were selected among monospecific stands of mature, lightly browsed $A$. nigrescens trees and defined as lightly browsed and lightly grazed (LL) $>7 \mathrm{~km}$ from a waterhole and $>3 \mathrm{~km}$ from other seasonal water sources. Grazing intensity was considered in our survey since environmental conditions created by the grass layer as well as grazer disturbance likely affect woody seedling establishment and recruitment (Brown and Archer, 1989; Davis et al., 1998). Sites were at least $1 \mathrm{~km}$ apart and a set of five plots, each $25 \mathrm{~m} \times 25 \mathrm{~m}$, was established within each site between June 2002 and June 2003; plots were randomly arranged and located at least $100 \mathrm{~m}$ apart.

Three soil samples (each $10 \mathrm{~cm}$ deep soil core of $5 \mathrm{~cm}$ diameter) were collected in the dry season in each plot and mixed to give one sample for analysis. Soil samples were dry when collected and stored in paper bags until analyzed for total $\mathrm{N}, \mathrm{NO}_{3}, \mathrm{NH}_{4}$, total $\mathrm{P}$, extractable cations ( $\mathrm{Ca}, \mathrm{Mg}, \mathrm{K}$, and $\mathrm{Na}$ ), $\mathrm{pH}$, and cation exchange capacity (CEC). Soil depth was checked using a manual auger digging $30 \mathrm{~cm}$ away from the place where each soil sample was collected.

Browsing intensity was measured on a total of 108 focal trees of A. nigrescens (12 trees per site) distributed among plots in the mid-dry season. The number of plant shoots that had been browsed during the current growing season was expressed as a percentage of a total of 20 shoots randomly chosen around the tree canopy ranging in height between 1 and $4 \mathrm{~m}$. Specifically, five shoots per browsing height class (1.5, 2, 3, and $4 \mathrm{~m}$ above ground) were checked all around the tree canopy for signs of recent browsing. Each of four shoots was selected from the portion of tree canopy facing one of the four cardinal points while the fifth shoot was selected from a portion of canopy exposed between two selected shoots and varied in different trees. The number of pods was counted all around the canopy of each Acacia tree in each plot and the number of flowering trees of $A$. 
nigrescens was recorded as well in September 2002 and September 2003. To compare browsing effects on canopy architecture, 10 external branches were randomly chosen on 10 Acacia trees $>2 \mathrm{~m}$ in height in each site. The length of the first five branch internodes from the canopy surface inwards was measured with string.

Grazing intensity was assessed using quadrat sampling at the end of the growing season in February 2003 and in June 2003. Eight quadrats $\left(1 \mathrm{~m}^{2}\right)$ were randomly positioned per plot and inside each quadrat we recorded the number of grass tufts, the average height of the grass layer from ground up to the base of the inflorescence, the total ground area covered by the tufts (estimated as the grass canopy projection on the ground), the mean number of green stems higher than $5 \mathrm{~cm}$, and the percentage of recently grazed stems (i.e. culms).

All woody species were identified and each individual per species was classified by height $(0-1,1-2,2-4$, and $>4 \mathrm{~m})$. Using field observations and published literature, woody plant species were sorted according to a combination of three functional traits: spinescence, evergreenness, and foliage acceptability to browsing ungulates. We considered spinescent those species bearing all kinds of spines, thorns, and prickles that defend foliage against ungulate browsers (see Cooper and Owen-Smith, 1986). We classified deciduous and evergreen woody plants after our 2-year field study observations and according to the literature (Coates Palgrave et al., 2002). Classification of species by the acceptability of their foliage to browsers was based on the definition given by OwenSmith and Cooper (1987). As in their study we placed plants in two categories: (1) palatable species are highly acceptable throughout the year and (2) unpalatable species are acceptable only in restricted periods. The degree of acceptability of our species was derived by field observations and literature (see du Toit, 2003; Owen-Smith, 1979; Owen-Smith and Cooper, 1987). Usually few plants have intermediate acceptability (Owen-Smith and Cooper, 1987) being in general either accepted or rejected by herbivores. Hence, because 'palatable' plants are often also 'acceptable' whereas 'unpalatable' plants are often less-acceptable we use the terms 'palatable' and 'acceptable' interchangeably throughout the manuscript. 


\section{Data analysis}

We first tested for significant effects of distance from permanent surface water on browsing and grazing intensity. We used univariate regressions with distance from water as predictor variable and percentage of browsed tree shoots as well as percentage of grazed grass culms as response variables. We also used univariate regressions to address potential significant effects of browsing intensity (expressed as percentage of browsed shoots) on pod number and internode length in tree branches of $A$. nigrescens individuals. Because of potential effects of spatial heterogeneity across the nine sites, we used multiple regressions to address the effects of browsing and grazing intensity (predictor variables) on different soil parameters. Once we identified the sub-set of soil parameters that most significantly varied according to browsing-grazing intensity (i.e. total soil $\mathrm{N}$, CEC, and topsoil depth; see Section 4), we sought to separate the potential effects of mammalian herbivory and soil parameters on woody species richness and composition. We first performed a multiple regression analysis to test for the effects of our predictor variables (herbivory and soil) on the number of species measured in each plot. Next, we performed a multivariate analysis to test for the effects of herbivory and soil parameters on species composition (i.e. species distribution across sites). We used CANOCO program version 4.5 (Lepš and Šmilauer, 2003) and calculated an unconstrained ordination using detrended correspondence analysis (DCA). This was done to measure the beta diversity in community composition along the ordination axes. The length of the first axis was 1.681, which made us to assume a linear response of species variation according to herbivory and soil properties. We therefore performed a constrained ordination, redundancy analysis (RDA) with standardization by samples and permutation tests (Monte Carlo test with 499 permutations) to assess whether at least one of the predictor variables had some effects on species composition. We then calculated two separate partial constrained ordinations using herbivory as the environmental variable and soil parameters as the covariable and vice-versa. This was to test for the effects of herbivory that could not be explained by the effects of soil, and the effects of soil that could not be explained by herbivory. Finally, we performed a RDA to test for the effects of herbivory and soil on the distribution of woody species according to a combination of specific traits such as spinescence, evergreenness, and foliage acceptability. 


\section{Results}

\subsection{Effects of distance from permanent surface water on browsing and grazing intensity}

The proportion of browsed shoots significantly increased in proximity of permanent surface water $\left(R^{2}=0.77, F_{1,44}=151, P<0.0001\right.$; Fig. 1$)$. Similarly, grass morphological parameters showed significant variation according to distance from surface water. The number of grazed culms was significantly higher close to surface water $\left(R^{2}=0.36\right.$, $F_{1,44}=24.6, P<0.0001$; Fig. 1), whereas tufts mean height $\left(R^{2}=0.45, F_{1,44}=30.2\right.$, $P<0.0001)$, tufts ground cover $\left(R^{2}=0.39, F_{1,44}=26.8, P<0.0001\right)$, and number of green stems taller than $5 \mathrm{~cm}\left(R^{2}=0.2, F_{1,44}=18.6, P<0.001\right)$ all significantly increased with the distance from surface water. Tufts number was independent of distance from surface water $\left(R^{2}=0.09, F_{1,44}=2.34, P=0.67\right)$.

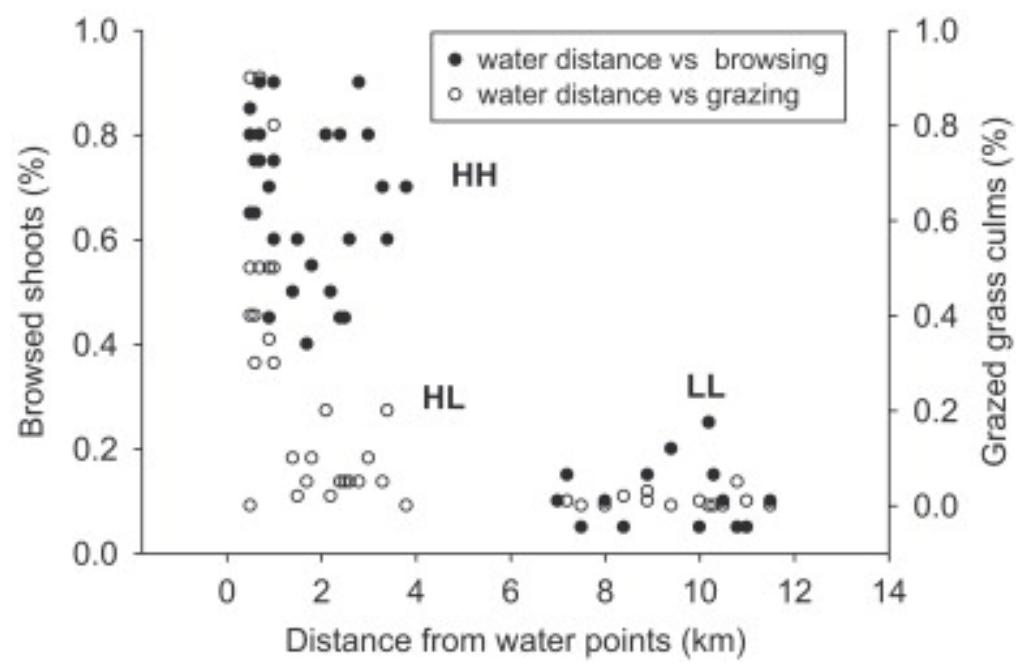

Fig. 1. Dependence of browsing and grazing intensity on distance from permanent surface water. Browsing intensity was expressed as the percentage of browsed shoots around Acacia nigrescens tree canopies during the current growing season (see Section 2). Grazing intensity was measured by using $1 \mathrm{~m}^{2}$ quadrats across the study sites at the end of the growing season (see Section 2). HH, high-browsing, high-grazing, HL, highbrowsing, low-grazing; and LL, low-browsing, low-grazing. 


\subsection{Effects of ungulate browsing on pod production and internode length}

We found that both the number of pod produced by A. nigrescens trees and the averaged internode length of external tree branches significantly decreased with browsing intensity (Fig. 2a and b). This suggests a strong effect of ungulate browsers on tree canopy shape and volume and the ability of heavily browsed trees to reproduce. However, the number of flowering trees/ha was not significantly affected by browsing intensity $\left(R^{2}=0.04\right.$, $\left.F_{1,44}=1.78, P=0.23\right)$.
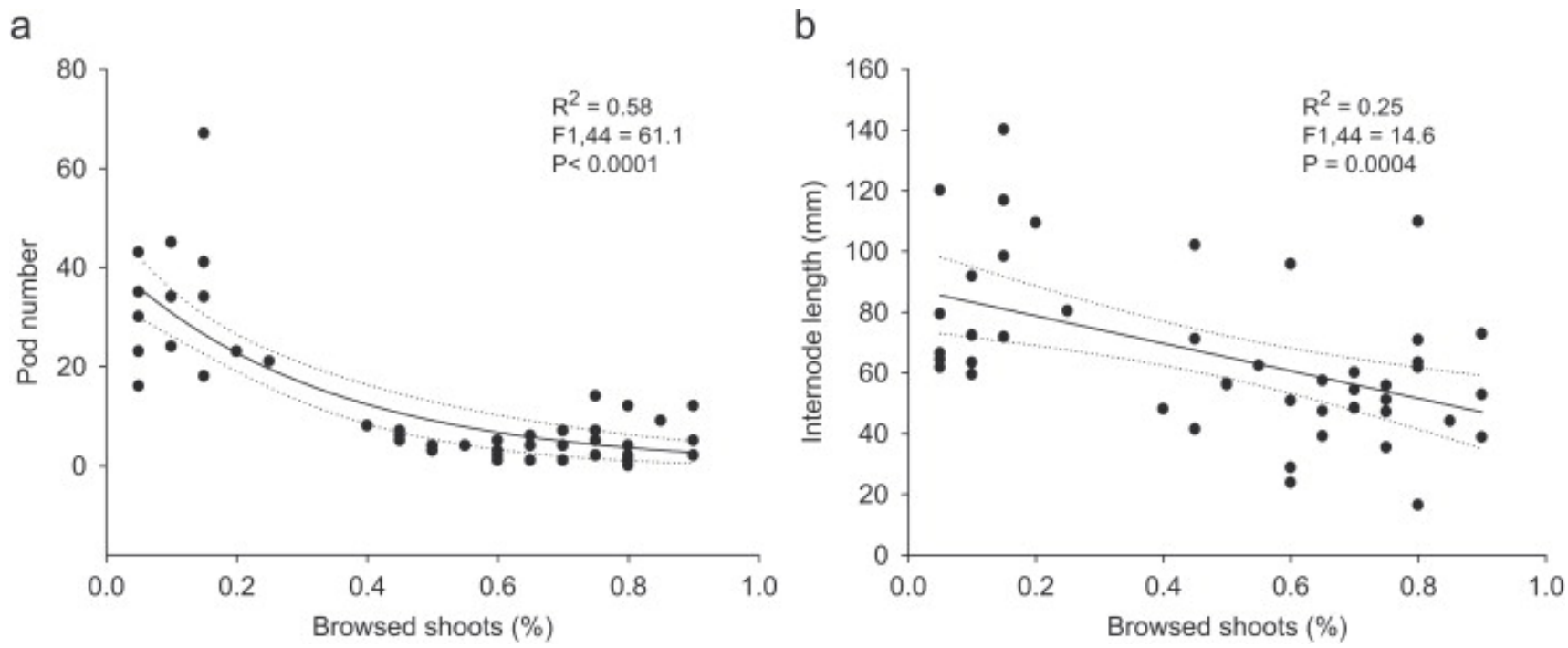

Fig. 2. Dependence of pod number (a) and internode length (b) on the number of browsed shoots measured around the canopy of A. nigrescens trees across the nine sites. Curves and regression lines result from simple asymptotic functions fitted to treatment means.

\subsection{Effects of browsing and grazing intensity on soil parameters}

Soil parameters measured across the nine sites are listed in Table 1 according to browsing-grazing intensity. Overall soil parameters varied more significantly according to grazing intensity rather than browsing intensity (Table 2). Total soil $\mathrm{N}$, soil cation concentrations, and $\mathrm{CEC}$ were significantly affected by ungulate grazing (Table 2). Most of these parameters were negatively related to grazing intensity included total soil $\mathrm{N}$ which was depleted at heavily grazed sites. We did not find significant effects of grazing intensity on $\mathrm{NO}_{3}$ and $\mathrm{P}$ concentrations that may be related to the fact that our soil 
collection was done in the dry season when nutrient fluxes are much lower than those at the onset of the wet season. Browsing intensity was negatively related with soil depth (Table 2) with the lightly browsed sites showing deeper soils. Multiple regressions with grazing intensity, browsing intensity, and distance from water source as predictor variables and different soil parameters as response variables, show that grazing intensity was often the most significant variable affecting soil parameters ( $P<0.01$ for all analyses).

\section{Table 1.}

Soil parameters \pm SE from sites differing in browsing-grazing intensity

\begin{tabular}{|l|l|l|l|}
\hline & \multicolumn{3}{|l|}{ Browsing-grazing intensity } \\
\hline & HH & HL & LL \\
\hline $\mathrm{N}(\%)$ & $0.14 \pm 0.01$ & $0.18 \pm 0.01$ & $0.18 \pm 0.01$ \\
\hline $\mathrm{NH}_{4}(\mathrm{mg} / \mathrm{kg})$ & $75.6 \pm 2.37$ & $69.5 \pm 1.61$ & $73.2 \pm 2.47$ \\
\hline $\mathrm{NO}_{3}(\mathrm{mg} / \mathrm{kg})$ & $60.1 \pm 3.25$ & $66.1 \pm 9.83$ & $52.7 \pm 5.79$ \\
\hline $\mathrm{P}(\mathrm{mg} / \mathrm{kg})$ & $61.2 \pm 17.9$ & $57.7 \pm 8.60$ & $74.2 \pm 9.04$ \\
\hline $\mathrm{Ca}(\mathrm{mg} / \mathrm{kg})$ & $1615 \pm 77.8$ & $2810 \pm 223$ & $2785 \pm 209$ \\
\hline $\mathrm{K}(\mathrm{mg} / \mathrm{kg})$ & $477 \pm 34.5$ & $923 \pm 87.3$ & $1048 \pm 23.4$ \\
\hline $\mathrm{Mg}(\mathrm{mg} / \mathrm{kg})$ & $538 \pm 56.1$ & $704 \pm 36.2$ & $1021 \pm 142$ \\
\hline $\mathrm{Na}(\mathrm{mg} / \mathrm{kg})$ & $73.4 \pm 9.5$ & $107 \pm 11.3$ & $110 \pm 18.8$ \\
\hline $\mathrm{CEC}$ & $15.8 \pm 0.9$ & $24.7 \pm 1.30$ & $26.1 \pm 2.01$ \\
\hline $\mathrm{pH}$ & $6.76 \pm 0.04$ & $6.55 \pm 0.08$ & $6.77 \pm 0.03$ \\
\hline Top-soil depth (cm) & $32.5 \pm 5.7$ & $64.5 \pm 5.29$ & $92.6 \pm 10.2$ \\
\hline
\end{tabular}

$\mathrm{HH}$, high-browsing, high-grazing; HL, high-browsing, low-grazing; LL, low-browsing, low-grazing. 
Table 2.

Dependence of different soil parameters on browsing and grazing intensity

\begin{tabular}{|c|c|c|c|c|c|}
\hline \multirow{2}{*}{$\begin{array}{l}\text { Response } \\
\text { variables }\end{array}$} & \multicolumn{5}{|c|}{ Regression parameters } \\
\hline & Intercept & $\begin{array}{l}\text { Browsing } \\
\text { intensity }\end{array}$ & $\begin{array}{l}\text { Grazing } \\
\text { intensity }\end{array}$ & $\begin{array}{l}\text { Overall } \\
R^{2}\end{array}$ & $\begin{array}{l}\text { Overall } \\
F\end{array}$ \\
\hline Total N (\%) & 0.18 & $-0.006 \mathrm{NS}$ & $-0.08^{* * *}$ & 0.36 & $11.3 * * * *$ \\
\hline $\mathrm{NH}_{4}(\mathrm{mg} / \mathrm{kg})$ & $71 * * * *$ & $5.14 \mathrm{NS}$ & $-4.07 \mathrm{NS}$ & 0.008 & $0.18 \mathrm{NS}$ \\
\hline $\mathrm{NO}_{3}(\mathrm{mg} / \mathrm{kg})$ & $54.1 * * * *$ & $14.4 \mathrm{NS}$ & $-7.2 \mathrm{NS}$ & 0.04 & $1.05 \mathrm{NS}$ \\
\hline $\mathrm{P}(\mathrm{mg} / \mathrm{kg})$ & $73.4 * * * *$ & $-21 \mathrm{NS}$ & $5.16 \mathrm{NS}$ & 0.04 & $0.97 \mathrm{NS}$ \\
\hline $\mathrm{Ca}(\mathrm{mg} / \mathrm{kg})$ & $2776^{* * * *}$ & $33.4 \mathrm{NS}$ & $-2064 * * * *$ & 0.54 & $25.1 * * * *$ \\
\hline $\mathrm{K}(\mathrm{mg} / \mathrm{kg})$ & $1055 * * * *$ & $-215 \mathrm{NS}$ & $-708 * * * *$ & 0.53 & $23.9 * * * *$ \\
\hline $\mathrm{Mg}(\mathrm{mg} / \mathrm{kg})$ & $1051 * * * *$ & $-477 * * * *$ & $-332 *$ & 0.58 & $29.1 * * * *$ \\
\hline $\mathrm{Na}(\mathrm{mg} / \mathrm{kg})$ & $114 * * * *$ & $-13.4 \mathrm{NS}$ & $-58.4 * *$ & 0.27 & $7.9 * *$ \\
\hline CEC & $26.8 * * * *$ & $-4.4 \mathrm{NS}$ & $-12.8 * * * *$ & 0.52 & $22.7 * * * *$ \\
\hline $\mathrm{pH}$ & $6.74 * * * *$ & $-0.21 \mathrm{NS}$ & $0.27 *$ & 0.12 & $2.93 \mathrm{NS}$ \\
\hline $\begin{array}{l}\text { Top-soil depth } \\
\text { (cm) }\end{array}$ & $96.7 * * * *$ & $-53.7 * *$ & $-38 \mathrm{NS}$ & 0.41 & $14.9 * * * *$ \\
\hline
\end{tabular}

Browsing intensity was measured on 108 trees of Acacia nigrescens and expressed as the percentage of browsed shoots on a total of 20 randomly selected around each tree canopy ranging in height between 1 and $4 \mathrm{~m}$ (the averaged value from four trees per plot was used for analyses). Grazing intensity was estimated by measuring the number of grazed culms from grass tufts included in each of 360 quadrats across the study sites (the averaged value from 8 quadrats per plot was used for analyses). Regressions have d.f. $=2,44$.

$\mathrm{NS}=$ not significant.

${ }^{*} P<0.05 ;{ }^{*} P<0.01 ; * * * P<0.001 ; * * * * P<0.0001$. 


\subsection{Plant community composition and species distribution}

From the multiple regression summary in Table 3, we inferred that none of the five predictor variables affected species richness expressed as mean number of species measured in each plot across different sites (see Appendix 1). However, results from RDA show that herbivory and soil parameters could explain $79 \%$ of the total variability in species composition (Fig. 3). The first two ordination axes explained $60 \%$ of species variability, whereas the Monte Carlo permutation test of all canonical axes was significant $($ Trace $=0.79 ; F=2.25 ; P=0.014$ ). The ordination diagram suggests that browsing-grazing categories (HH, HL, and LL) are characterized by different species assemblages and the HL and LL category are positively correlated with soil parameters (Fig. 3). A. nigrescens shows a very low fit on the first two ordination axes which suggests its distribution is quite independent of herbivory and soil (Fig. 3). When we used browsing-grazing as the predictor variable and soil parameters as covariable, we found that browsing-grazing intensity could explain alone $22.6 \%$ of the species variability. On the other hand, when we used soil parameters as predictor variable and browsing-grazing intensity as covariable, the total variation explained was $20.5 \%$. The Monte Carlo permutation tests suggest, however, that none of the two predictor variables is more important than the other in explaining species variability. Finally, results of RDA with permutations show that variation in plant community composition, as described by a combination of three functional traits, was independent from herbivory intensity (Trace $=0.3 ; F=1.28 ; P=0.35 ;$ Fig. 4 ). 
Table 3.

Dependence of number of woody species averaged in each of 45 plots established across the nine study sites on browsing intensity, grazing intensity, top-soil depth, total soil $\mathrm{N}$ $(\%)$, and cation exchange capacity (CEC)

\begin{tabular}{|c|c|c|c|}
\hline \multirow[t]{2}{*}{$\begin{array}{l}\text { Regression } \\
\text { parameters }\end{array}$} & \multicolumn{3}{|c|}{$\begin{array}{l}\text { Response variable=number of plant species } R^{2}=0.12 \text {, } \\
F_{5,44}=1.15, P=0.34\end{array}$} \\
\hline & Estimate & $t$-ratio & $\boldsymbol{P}$ \\
\hline Intercept & 116.5 & 2.31 & 0.02 \\
\hline Browsing intensity & -23.8 & -0.91 & 0.36 \\
\hline Grazing intensity & -32.0 & -0.90 & 0.36 \\
\hline Top-soil depth (cm) & 0.2 & 0.93 & 0.35 \\
\hline Total N (\%) & 70 & 0.34 & 0.73 \\
\hline $\mathrm{CEC}$ & -2.51 & -1.64 & 0.11 \\
\hline
\end{tabular}

Multiple regression has d.f. $=5.44$.

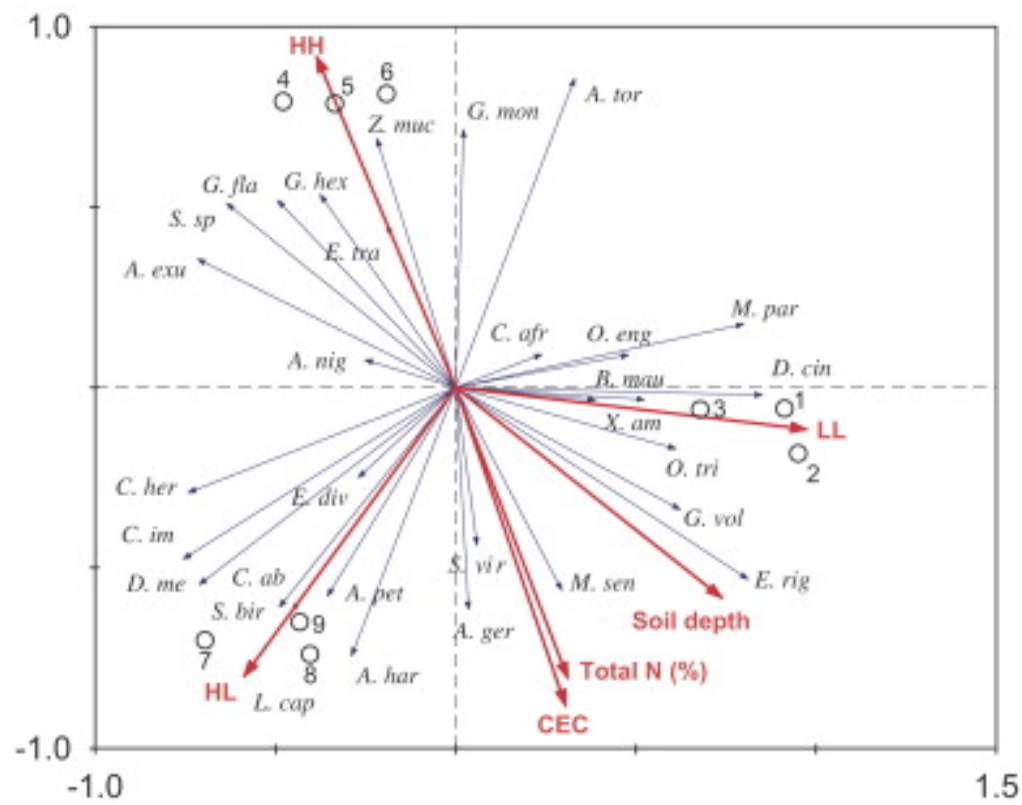

Fig. 3. Ordination diagram of RDA with species richness distribution plotted as arrows (thin lines) and browsing-grazing intensity (HH, high-high; HL, high-low; and LL, lowlow), total soil $\mathrm{N} \%$, soil depth and soil CEC plotted as arrows (heavy lines). We also represented the nine study sites by numbered circles. Acacia exuvialis (A. exu), Acacia 
gerrardii (A. ger), Acacia nigrescens (A. nig), Acacia tortilis (A. tor), Albizia harveyi (A. har), Albizia petersiana (A. pet), Balanites maughamii (B. mau), Cassia abbreviata (C. ab), Combretum hereroense (C. her), Combretum imberbe (C. im), Commiphora africana (C. afr), Dalbergia melanoxylon (D. me), Dichrostachys cinerea (D. cin), Eheritia rigida (E. rig), Elaeodendron transvaalense (E. tra), Euclea divinorum (E. div), Gardenia volkensii (G. vol), Grewia flavescens (G. fla), Grewia hexamita (G. hex), Grewia monticola (G. mon), Maytenus senegalensis (M. sen), Lonchocarpus capassa (L. cap), Maerua parvifolia (M. par), Ozoroa engleri (O. eng), Ormocarpum trichocarpum (O. tri), Sclerocarya birrea (S. bir), Securinega virosa (S. vir), Solanum sp. (S. sp), Ximenia americana (X. afr), Ziziphus mucronata (Z. muc).

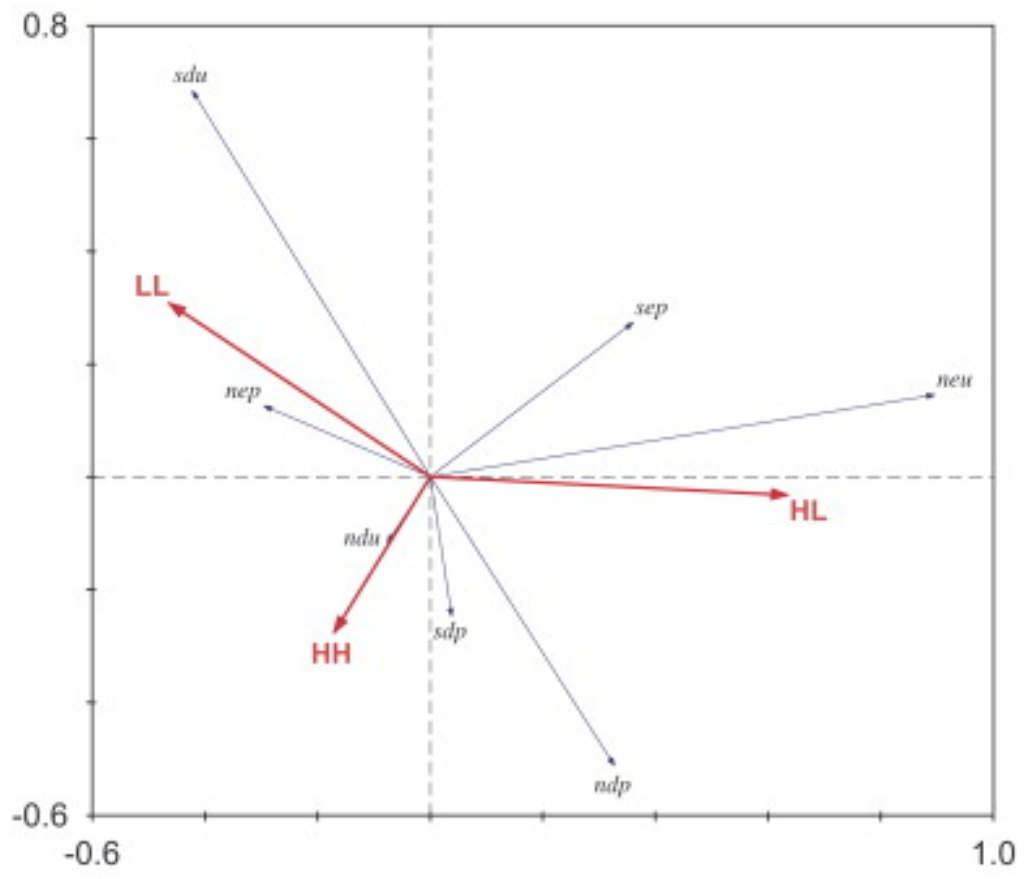

Fig. 4. Ordination diagram of RDA with browsing-grazing intensity and the measured plant functional traits expressed as the combination of spinescence-evergreenesspalatability (abbreviations as in Fig. 3). sdu, spinescent-deciduous-unpreferred; sdp, spinescent-deciduous-preferred; ndu, nonspinescent-deciduous-unpreferred; ndp, nonspinescent-deciduous-preferred; sep, spinescent-evergreen-preferred; neu, nonspinescent-evergreen-unpreferred. 


\section{Discussion}

Our first prediction was confirmed in that Acacia trees at lightly browsed sites had wider canopies and branches with longer internodes than trees at heavily browsed sites. This agrees with the results of similar studies in temperate forests that recognized general negative effects of tree pruning on canopy physiognomy and tree height of palatable woody species (Brookshire et al., 2002; Heroldova et al., 2003; Motta, 2003; Relva and Veblen, 1998). Short internodes contribute to reduce canopy volume in heavily browsed Acacia trees and increase side-branching on pruned shoots because of suppression of apical dominance (du Toit et al., 1990). Our results also confirm the findings of a recent study that showed negative effects of tree pruning on the reproductive ability of Acacia drepanolobium in an eastern African savanna (Goheen et al., 2007).

We also found that soil nutrient concentrations significantly decreased at high grazing intensity (our second prediction). This resulted in heavily grazed sites being low in soil $\mathrm{N}$ and cations while the plant-available $\mathrm{N}$ pool $\left(\mathrm{NH}_{4}\right.$ and $\left.\mathrm{NO}_{3}\right)$ did not differ between heavily and lightly grazed sites, possibly because this was compensated in animal dung and urine (Augustine et al., 2003). However, our results do not indicate a strong positive feedback between large herbivores and the more labile soil $\mathrm{N}$ pool as described in a managed savanna ecosystem (Augustine et al., 2003), possibly because Kruger is a natural system without livestock to contribute to higher local returns of dung and urine. Nevertheless, if any positive feedback on nutrient cycling is likely to occur it will be detected during the wet season when microbial activity and nutrient mineralization rates are high. Finally, the difference in cation concentration between $\mathrm{HH}$ and LL sites is also driven by the higher soil clay content in the latter sites, which has the property to attract and retain positively charged ions.

The strong effect of browsing on tree reproduction and morphology and the lower total soil nutrients at $\mathrm{HH}$ sites could trigger changes in woody plant community composition. General negative effects of browsers on community-level representation of plant functional types have been well described in high latitudes, where selective browsing reduces the local abundance of palatable deciduous woody plants and contributes to the 
early dominance of unpalatable, evergreen and slow-growing species in the vegetation succession (Pastor et al., 1988; Seagle and Liang, 2001; Wardle et al., 2001). We did not find such changes in the arid eutrophic plains of central Kruger and although soil properties and browsing intensity together explained $79 \%$ of the total variability in species composition, the separate effects of browsing and soil remained unclear. One potential explanation for the lack of changes in species composition under high browsing intensity is that in semi-arid eutrophic African savannas the demography and distribution of palatable woody plant species depends upon their compensatory growth and resprouting abilities (Augustine and McNaughton, 1998; Bond and van Wilgen, 1996; du Toit et al., 1990; Higgins et al., 2000). Many woody species of arid, semi-arid, and fire prone ecosystems such as African savannas, Mediterranean shrub-lands, and chaparral (Bond and van Wilgen, 1996; Espelta et al., 2003; Higgins et al., 2000), appear to be very resilient to chronic browsing and are able to persist in situ over long periods. This might also explain the lack of evidence for a browsing effect on the mix of species in the woody plant community when functionally classified by evergreeness, spinescence, and foliage acceptability. The rejection of our third prediction was because the local abundance of A. nigrescens did not decrease at heavily browsed sites; presumably this species has coevolved with the browsing guild and is adapted for conditions of chronic browsing disturbance (Fornara and du Toit, 2007). We suggest the key adaptations include physical defences such as spines, thorns, and prickles (Bryant et al., 1989; OwenSmith and Cooper, 1987), together with increased mass compensatory growth abilities of adult trees and resprouting abilities of saplings. Physical defences are effective in limiting foliage loss to browsers (Cooper and Owen-Smith, 1986; Gowda, 1996) and represent a cheap form of defence in semi-arid eutrophic savannas, especially if amortized over many years (Craine et al., 2003). It remains, however, unclear how palatable woody plants with physical defences also have high compensatory growth abilities. More research is needed to address the importance of different mechanisms that could make nutrients available to support plant compensatory growth and increase plant resilience to tree pruning, such as root mining, N2-fixation, litter decomposition, nutrient fluxes from dung, high soil nutrient cycling, etc. 
Overall our study suggests that, in a semi-arid eutrophic southern African savanna, resilient-spinescent woody plants can maintain community dominance even under conditions of chronic ungulate browsing. This is despite the foliage of such plants being the staple food supply of browsing ungulates. The important implication is that browsing ungulates should not be expected to influence the functional composition of savanna plant communities, and therefore nutrient cycling processes, in ways predicted from previous classic studies of browsing systems, which have largely been conducted in boreal forests (Kielland and Bryant, 1998; Pastor and Naiman, 1992; Pastor et al., 1988).

\section{References}

Augustine and McNaughton, 1998 D.J. Augustine and S.J. McNaughton, Ungulate effects on the functional species composition of plant communities: herbivore selectivity and plant tolerance, Journal of Wildlife Management 62 (1998), pp. 1165-1183.

Augustine and McNaughton, 2004 D.J. Augustine and S.J. McNaughton, Regulation of shrub dynamics by native browsing ungulates on East African rangeland, Journal of Applied Ecology 41 (2004), pp. 45-58.

Augustine et al., 2003 D.J. Augustine, S.J. McNaughton and D.A. Frank, Feedbacks between soil nutrients and large herbivores in a managed savanna ecosystem, Ecological Applications 13 (2003), pp. 1325-1337.

Belsky, 1984 A.J. Belsky, Role of small browsing mammals in preventing woodland regeneration in the Serengeti National Park, Tanzania, African Journal of Ecology 22 (1984), pp. 271-279.

Bond and Loffell, 2003 W.J. Bond and D. Loffell, Introduction of giraffe changes acacia distribution in a South African savanna, African Journal of Ecology 39 (2003), pp. 286294. 
Bond and van Wilgen, 1996 W.J. Bond and B.W. van Wilgen, Fire and Plants, Chapman \& Hall, London, UK (1996) 261pp.

Brookshire et al., 2002 E.N.J. Brookshire, J.B. Kauffman, D. Lytjen and N. Otting, Cumulative effects of wild ungulate and livestock herbivory on riparian willows, Oecologia 132 (2002), pp. 559-566.

Brown and Archer, 1989 J.R. Brown and S. Archer, Woody plant invasion of grasslands: establishment of honey mesquite (Prosopis glandulosa var. glandulosa) on sites differing in herbaceous biomass and grazing history, Oecologia 80 (1989), pp. 19-26.

Bryant et al., 1989 J.P. Bryant, P.J. Kuropat, S.M. Cooper, K. Frisby and N. Owen-Smith, Resource availability hypothesis of plant antiherbivore defence tested in a South African savanna ecosystem, Nature 340 (1989), pp. 227-229.

Coates Palgrave et al., 2002 K. Coates Palgrave, M. Coates Palgrave, R.B. Drummond and E.J. Moll, Trees of Southern Africa (third ed), Struik Publishers (2002).

Cooper and Owen-Smith, 1986 S.M. Cooper and N. Owen-Smith, Effects of plant spinescence on large mammalian herbivores, Oecologia 68 (1986), pp. 446-455

Craine et al., 2003 J. Craine, W. Bond, W.G. Lee, P.B. Reich and S. Ollinger, The resource economics of chemical and structural defenses across nitrogen supply gradients, Oecologia 137 (2003), pp. 547-556.

Davis et al., 1998 M.A. Davis, K.J. Wrange and P.B. Reich, Competition between tree seedlings and herbaceous vegetation: support for a theory of resource supply and demand, Journal of Ecology 86 (1998), pp. 652-661. 
Diamond, 1986 J. Diamond, Overview: laboratory experiments, field experiments, and natural experiments. In: J. Diamond and T.J. Case, Editors, Community Ecology, Harper \& Row, New York (1986), pp. 3-22.

du Toit, 2003 J.T. du Toit, Large herbivores and savanna heterogeneity. In: J.T. du Toit, K.H. Rogers and H.C. Biggs, Editors, The Kruger Experience. Ecology and Management of Savanna Heterogeneity, Island Press, Washington, DC, USA (2003), pp. 292-309.

du Toit and Owen-Smith, 1989 J.T. du Toit and N. Owen-Smith, Body size, population metabolism, and habitat specialization among large African herbivores, American Naturalist 133 (1989), pp. 736-740.

du Toit et al., 1990 J.T. du Toit, J.P. Bryant and K. Frisby, Regrowth and palatability of Acacia shoots following pruning by African Savanna browsers, Ecology 71 (1990), pp. $140-154$.

Eckhardt et al., 2000 H.C. Eckhardt, B.W. van Wilgen and H.C. Biggs, Trends in woody vegetation cover in the Kruger National Park, South Africa, between 1940 and 1998, African Journal of Ecology 38 (2000), pp. 108-115.

Espelta et al., 2003 J.M. Espelta, J. Retana and A. Habrouk, Resprouting patterns after fire and response to stool cleaning of two coexisting mediterranean oaks with contrasting leaf habits on two different sites, Forest Ecology and Management 179 (2003), pp. 401414.

Fornara and du Toit, 2007 D.A. Fornara and J.T. du Toit, Browsing lawns? Responses of Acacia nigrescens to ungulate browsing in an African savanna, Ecology 88 (2007), pp. 200-209. 
Fritz et al., 2002 H. Fritz, P. Duncan, I.J. Gordon and A.W. Illius, Megaherbivores influence trophic guilds structure in African ungulate communities, Oecologia 131 (2002), pp. 620-625.

Goheen et al., 2007 J.R. Goheen, T.P. Young, F. Keesing and T.M. Palmer, Consequences of herbivory by native ungulates for the reproduction of a savanna tree, Journal of Ecology 95 (2007), pp. 129-138.

Gowda, 1996 J.H. Gowda, Spines of Acacia tortilis: what do they defend and how?, Oikos 77 (1996), pp. 279-284.

Harmer, 2001 R. Harmer, The effect of plant competition and simulated summer browsing by deer on tree regeneration, Journal of Applied Ecology 38 (2001), pp. 10941103.

Heikkilä and Härkönen, 1996 R. Heikkilä and S. Härkönen, Moose browsing in young Scots pine stands in relation to forest management, Forest Ecology and Management $\mathbf{8 8}$ (1996), pp. 179-186.

Heroldova et al., 2003 M. Heroldova, M. Homolka and J. Kamler, Breakage of rowan caused by red deer, an important factor for Sorbeto-Piceetum stand regeneration?, Forest Ecology and Management 181 (2003), pp. 131-138.

Higgins et al., 2000 S.I. Higgins, W.J. Bond and W.S. Trollope, Fire, resprouting and variability: a recipe for grass-tree

Horsley et al., 2003 S.B. Horsley, S.L. Stout and D.S. deCalesta, White-tailed deer impact on the vegetation dynamics of a northern hardwood forest, Ecology Applications 13 (2003), pp. 98-118. 
Jachmann and Bell, 1985 H. Jachmann and R.H.V. Bell, Utilization by elephants of the Brachystegia woodlands of Kasungu National Park, Malawi, African Journal of Ecology 23 (1985), pp. 245-258.

Jachmann and Croes, $1991 \mathrm{H}$. Jachmann and T. Croes, Effects of browsing by elephants on the Combretum/Terminalia woodland at the Nazinga Game Ranch, Burkina Faso, West Africa, Biological Conservation 57 (1991), pp. 13-24.

Kielland and Bryant, 1998 K. Kielland and J.P. Bryant, Moose herbivory in taiga: effects on biogeochemistry and vegetation dynamics in primary succession, Oikos 82 (1998), pp. $377-383$.

Lepš and Šmilauer, 2003 J. Lepš and P. Šmilauer, Multivariate analysis of ecological data using CANOCO, Cambridge University Press, UK (2003) 269pp.

Mabunda et al., 2003 D. Mabunda, D.J. Pienaar and J. Verhoef, The Kruger National Park: a century of management and research. In: J.T. du Toit, K.H. Rogers and H.C. Biggs, Editors, The Kruger Experience. Ecology and Management of Savanna Heterogeneity, Island Press, Washington, DC, USA (2003), pp. 3-21.

McInnes et al., 1992 P.F. McInnes, R.J. Naiman, J. Pastor and Y. Cohen, Effects of moose browsing on vegetation and litter of the boreal forest, Isle Royale, Michigan, USA, Ecology 73 (1992), pp. 2059-2075.

McNaughton and Georgiadis, 1986 S.J. McNaughton and N.J. Georgiadis, Ecology of African grazing and browsing mammals, Annual Review of Ecology and Systematics 17 (1986), pp. 39-65.

McNaughton et al., 1988 S.J. McNaughton, R.W. Ruess and S.W. Seagle, Large mammals and process dynamics in African ecosystems, BioScience 38 (1988), pp. 794 800. 
Motta, 2003 R. Motta, Ungulate impact on rowan (Sorbus aucuparia L.) and Norway spruce (Picea abies (L.) Karst.) height structure in mountain forests in the eastern Italian Alps, Forest Ecology and Management 181 (2003), pp. 139-150.

Naiman et al., 2003 R.J. Naiman, L. Braack, R. Grant, A.C. Kemp, J.T. du Toit and F.J. Venter, Interactions between species and ecosystem characteristics. In: J.T. du Toit, K.H. Rogers and H.C. Biggs, Editors, The Kruger Experience. Ecology and Management of Savanna Heterogeneity, Island Press, Washington, DC, USA (2003), pp. 221-241.

Oba and Post, 1999 G. Oba and E. Post, Browse production and offtake by free-ranging goats in an arid zone, Kenya, Journal of Arid Environments 43 (1999), pp. 183-195.

Olff et al., 2002 H. Olff, M.E. Ritchie and H.H.T. Prins, Global environmental controls of diversity in large herbivores, Nature 415 (2002), pp. 901-904.

Owen-Smith, 1979 N. Owen-Smith, Assessing the foraging efficiency of a large herbivore, the kudu, South African Journal of Wildlife Research 9 (1979), pp. 102-110. Owen-Smith, 1990 N. Owen-Smith, Demography of a large herbivore, the greater kudu Tragelaphus strepsiceros, in relation to rainfall, Journal of African Ecology 59 (1990), pp. 893-913.

Owen-Smith and Cooper, 1987 N. Owen-Smith and S.M. Cooper, Palatability of woody plants to browsing ruminants in a South African savanna, Ecology 68 (1987), pp. 319 333.

Pastor and Naiman, 1992 J. Pastor and R.J. Naiman, Selective foraging and ecosystem processes in boreal forests, American Naturalist 139 (1992), pp. 690-705.

Pastor et al., 1988 J. Pastor, R.J. Naiman, B. Dewey and P. McInnes, Moose, microbes, and the boreal forest, Bioscence 38 (1988), pp. 770-777. 
Peinetti et al., 2001 H.R. Peinetti, R.S.C. Menezes and M.B. Coughenour, Changes induced by elk browsing in the aboveground biomass production and distribution of willow (Salix monticola Bebb): their relationships with plant water, carbon, and nitrogen dynamics, Oecologia 127 (2001), pp. 334-342.

Pellew, 1983 R.A.P. Pellew, The impacts of elephant, giraffe and fire upon the Acacia tortilis woodlands of the Serengeti, Journal of African Ecology 21 (1983), pp. 41-74.

Prins and Douglas-Hamilton, 1990 H.H.T. Prins and I. Douglas-Hamilton, Stability in a multi-species assemblage of large herbivores in East Africa, Oecologia 83 (1990), pp. $392-400$.

Rao et al., 2003 S.J. Rao, G.R. Iason, I.A.R. Hulbert, M.J. Daniels and P.A. Racey, Tree browsing by mountain hares (Lepus timidus) in young Scots pine (Pinus sylvestris) and birch (Betula pendula) woodland, Forest Ecology and Management 176 (2003), pp. 459471.

Redfern et al., 2003 J.V. Redfern, C.C. Grant, H.C. Biggs and W.M. Getz, Surface water constraints on herbivore foraging in the Kruger National Park, South Africa, Ecology 84 (2003), pp. 2092-2107.

Relva and Veblen, 1998 M.R. Relva and T.T. Veblen, Impacts of introduced large herbivores on Austrocedrus chilensis forests in northern Patagonia, Argentina, Forest Ecology and Management 108 (1998), pp. 27-40.

Ritchie et al., 1998 M.E. Ritchie, D. Tilman and M.H. Knops, Herbivore effects on plant and nitrogen dynamics in oak savanna, Ecology 79 (1998), pp. 165-177. 
Seagle and Liang, 2001 S.W. Seagle and S.-Y. Liang, Application of a forest gap model for prediction of browsing effects on riparian forest succession, Ecological Modeling 144 (2001), pp. 213-229.

Tilghman, 1989 N.G. Tilghman, Impacts of white-tailed deer on forest regeneration in northwestern Pennsylvania, Journal of Wildlife Management 53 (1989), pp. 524-532.

Venter et al., 2003 F.J. Venter, R.J. Scholes and H.C. Eckhardt, The abiotic template and its associated vegetation pattern. In: J.T. du Toit, K.H. Rogers and H.C. Biggs, Editors, The Kruger Experience. Ecology and Management of Savanna Heterogeneity, Island Press, Washington, DC, USA (2003), pp. 83-129.

Wardle et al., 2001 D.A. Wardle, G.M. Barker, G.W. Yeates, K.I. Bonner and A. Ghani, Introduced browsing mammals in New Zealand natural forests: aboveground and belowground consequences, Ecological Monographs 71 (2001), pp. 587-614.

Whyte et al., 2003 I.J. Whyte, R.J. van Aarde and S.L. Pimm, Kruger's elephant population: its size and consequences for ecosystem heterogeneity. In: J.T. du Toit, K.H. Rogers and H.C. Biggs, Editors, The Kruger Experience. Ecology and Management of Savanna Heterogeneity, Island Press, Washington, DC, USA (2003), pp. 332-348. 


\section{Appendix 1.}

Plant density (stems/ha) and relative abundance (\%) for the woody species recorded across nine sites with different herbivory intensity (abbreviations as in Fig. 3 and Fig. 4).

\begin{tabular}{|c|c|c|c|c|c|c|c|}
\hline & \multirow[t]{2}{*}{$\begin{array}{l}\text { Plant } \\
\text { traits }\end{array}$} & \multicolumn{2}{|l|}{$\mathbf{L} \mathbf{L}$} & \multicolumn{2}{|l|}{ HL } & \multicolumn{2}{|l|}{ HH } \\
\hline & & Stems/ha & $\%$ & Stems/ha & $\%$ & Stems/ha & $\%$ \\
\hline Acacia exuvialis & $\operatorname{sdp}$ & - & - & $98.7 \pm 4.78$ & 7.86 & $64 \pm 2.68$ & 6.58 \\
\hline Acacia gerrardii & sdp & $6.6 \pm 0.04$ & 0.49 & $40 \pm 0.23$ & 0.18 & - & 0.00 \\
\hline Acacia nigrescens & sdp & $134.6 \pm 14.2$ & 9.98 & $332 \pm 13.2$ & 26.43 & $197 \pm 17.7$ & 20.3 \\
\hline Acacia tortilis & sdp & $42.7 \pm 2.1$ & 3.16 & $2.7 \pm 0.03$ & 0.21 & $101 \pm 1.26$ & 10.4 \\
\hline Albizia harveyii & $\mathrm{ndu}$ & $5.3 \pm 0.4$ & 0.4 & $44 \pm 0.20$ & 3.50 & $2.7 \pm 0.17$ & 0.27 \\
\hline Albizia petersiana & ndp & - & 0.00 & $2.7 \pm 0.03$ & 0.21 & - & 0.00 \\
\hline $\begin{array}{l}\text { Balanites } \\
\text { maughamii }\end{array}$ & sdu & $2.7 \pm 0.29$ & 0.2 & - & 0 & - & 0.00 \\
\hline Cassia abbreviata & ndp & - & 0.00 & $17.3 \pm 1.12$ & 1.38 & - & 0.00 \\
\hline $\begin{array}{l}\text { Combretum } \\
\text { hereroense }\end{array}$ & ndu & - & 0.00 & $105 \pm 3.7$ & 8.39 & $5.6 \pm 0.19$ & 0.55 \\
\hline $\begin{array}{l}\text { Combretum } \\
\text { imberbe }\end{array}$ & ndp & - & 0.00 & $14.7 \pm 0.07$ & 1.77 & $6.7 \pm 0.34$ & 0.69 \\
\hline $\begin{array}{l}\text { Commiphora } \\
\text { africana }\end{array}$ & sdp & $17 \pm 1.05$ & 1.28 & $7 \pm 0.11$ & 0.64 & $18.7 \pm 5.9$ & 1.92 \\
\hline $\begin{array}{l}\text { Dalbergia } \\
\text { melanoxylon }\end{array}$ & sdp & - & 0.00 & $33 \pm 02.86$ & 2.27 & $2.6 \pm 0.17$ & 0.27 \\
\hline $\begin{array}{l}\text { Dichrostachys } \\
\text { cinerea }\end{array}$ & sdp & $154.7 \pm 38.2$ & 11.5 & $108 \pm 5.1$ & 8.60 & $67 \pm 4.17$ & 9.19 \\
\hline Eheritia rigida & ndu & $158.6 \pm 27.3$ & 11.8 & $17.3 \pm 0.10$ & 1.38 & $1.3 \pm 0.08$ & 0.14 \\
\hline $\begin{array}{l}\text { Elaeodendron } \\
\text { transvaal }\end{array}$ & ndp & - & 0.00 & - & 0 & $1.3 \pm 0.08$ & 0.14 \\
\hline Euclea divinorum & neu & $1.3 \pm 0.14$ & 0.1 & $8 \pm 0.09$ & 0.64 & $2.7 \pm 0.17$ & 0.27 \\
\hline Gardenia volkensii & ndp & $17.3 \pm 0.92$ & 1.28 & $6.7 \pm 0.07$ & 0.53 & - & 0.00 \\
\hline
\end{tabular}




\begin{tabular}{|l|l|l|l|l|l|l|l|}
\hline & $\begin{array}{l}\text { Plant } \\
\text { traits }\end{array}$ & \multicolumn{2}{l}{ LL } & \multicolumn{2}{l|}{ HL } & \multicolumn{2}{l|}{ HH } \\
\hline & & Stems/ha & $\%$ & Stems/ha & $\%$ & Stems/ha & $\%$ \\
\hline Grewia flavescens & ndp & $1.3 \pm 0.14$ & 0.1 & $8 \pm 0.06$ & 0.64 & $25 \pm 0.54$ & 2.61 \\
\hline Grewia hexamita & ndu & - & 0.00 & $1.3 \pm 0.02$ & 0.11 & $9.3 \pm 0.29$ & 0.96 \\
\hline Grewia monticola & ndu & $7 \pm 0.31$ & 0.49 & $2.7 \pm 0.03$ & 0.21 & $57 \pm 1.25$ & 5.90 \\
\hline $\begin{array}{l}\text { Maytenus } \\
\text { senegalensis }\end{array}$ & sep & $24 \pm 1.14$ & 1.78 & $78 \pm 0.52$ & 6.26 & $8 \pm 0.29$ & 0.82 \\
\hline Maerua parvifolia & nep & $633 \pm 25$ & 46.1 & $8 \pm 0.08$ & 0.64 & $66.7 \pm 3.55$ & 6.86 \\
\hline $\begin{array}{l}\text { Lonchocarpus } \\
\text { capassa }\end{array}$ & nep & - & 0.00 & $32 \pm 0.21$ & 2.55 & - & 0.00 \\
\hline $\begin{array}{l}\text { Ormocarpum } \\
\text { trichocarpum }\end{array}$ & nep & $84 \pm 2.75$ & 6.23 & $36 \pm 0.22$ & 2.87 & $8 \pm 0.42$ & 0.82 \\
\hline Sclerocarya birrea & ndp & - & 0.00 & $25 \pm 0.2$ & 2.02 & - & 0.00 \\
\hline Securinega virosa & ndp & $28 \pm 1.77$ & 2.08 & $42 \pm 2.2$ & 3.40 & $13.3 \pm 0.39$ & 1.37 \\
\hline Solanum sp. & ndu & $9.4 \pm 0.87$ & 0.69 & $180 \pm 2.04$ & 14.33 & $274 \pm 7.04$ & 28.3 \\
\hline Ximenia americana & sdp & $6.6 \pm 0.52$ & 0.49 & - & 0 & - & 0.00 \\
\hline Ziziphus mucronata & sdp & - & 0 & - & 0 & $14.7 \pm 1.29$ & 1.51 \\
\hline Total & & 1349 & 100 & 1256 & 100 & 972 & 100 \\
\hline
\end{tabular}

Corresponding author. Department of Ecology, Evolution and Behavior, University of Minnesota, 1987 Upper Buford Circle, Ecology Building. St. Paul, MN 55108, USA. Tel.: +1 6126255738 . 